\title{
MICROSTRUCTURE EVOLUTION OF ADVANCED HIGH-STRENGTH TRIP-AIDED BAINITIC STEEL
}

\author{
RAZVOJ MIKROSTRUKTURE NAPREDNEGA \\ VISOKOTRDNOSTNEGA BAINITNEGA JEKLA Z UPORABO TRIP
}

\author{
Adam Grajcar \\ Silesian University of Technology, Institute of Engineering Materials and Biomaterials, Konarskiego Street 18a, 44-100 Gliwice, Poland \\ adam.grajcar@polsl.pl \\ Prejem rokopisa - received: 2014-08-01; sprejem za objavo - accepted for publication: 2014-10-08
}

doi:10.17222/mit.2014.154

The present work is focused on monitoring the microstructure evolution of the thermomechanically rolled medium-C steel containing $\mathrm{Si}$ and $\mathrm{Al}$ to prevent the precipitation of carbides. The initial microstructure consists of carbide-free bainite, polygonal ferrite and blocky-type and interlath retained austenite. To monitor the transformation behaviour of the retained austenite transforming into strain-induced martensite, tensile tests were interrupted at particular strains $(5 \%, 10 \%, 15 \%, 18.4$ $\%)$. The amount of the retained austenite determined with XRD and EBSD techniques decreased from $17 \%$ to $6.8 \%$ upon straining, which was related to the transformation-induced plasticity effect. The identification of the retained austenite and strain-induced martensite was carried out using an electron scanning microscope equipped with EBSD (electron backscatter diffraction). It was found that sheet samples are strongly strengthened by the transformation of the blocky retained austenite, whereas the layers and films of the $\gamma$ phase are over-stabilized and they do not transform into martensite.

Keywords: AHSS, bainitic steel, retained austenite, thermomechanical treatment, TRIP effect, strain-induced martensite

Delo obravnava pregled razvoja mikrostrukture pri termomehanskem valjanju srednje ogljičnega jekla s Si in Al, ki preprečita izločanje karbidov. Začetna mikrostruktura je bila iz bainita brez karbidov, poligonalnega ferita ter zaostalega avstenita kockaste oblike in zaostalega avstenita med lamelami. Za spremljanje vedenja zaostalega avstenita pri pretvorbi v deformacijsko induciran martenzit so bili natezni preizkusi prekinjeni pri posameznih raztezkih (5\%,10\%, 15\%, 18,4 \%). Delež zaostalega avstenita, določen z XRD in EBSD, se je zmanjšal po natezni deformaciji iz $17 \%$ na $6,8 \%$, kar je posledica vpliva $\mathrm{z}$ deformacijo povzročene pretvorbe na plastičnost. Identifikacija zaostalega avstenita in napetostno induciranega martenzita je bila izvršena z vrstičnim elektronskim mikroskopom, opremljenim z EBSD (difrakcija odbitih elektronov). Ugotovljeno je, da se vzorci pločevine bolj utrjujejo s pretvorbo kockastega zaostalega avstenita, medtem ko so plasti in sloji $\gamma$-faze bolj stabilizirani in se ne pretvorijo $\mathrm{v}$ martenzit.

Ključne besede: AHSS, bainitno jeklo, zaostali avstenit, termomehanska obdelava, učinek TRIP, napetostno induciran martenzit

\section{INTRODUCTION}

Advanced high-strength steels (AHSS) for the automotive industry cover a wide group of multiphase steels showing a superior balance between the strength and plasticity. Dual-phase (DP), complex-phase (CP) and transformation-induced plasticity (TRIP) steels are representatives of the AHSSs containing ferrite as the main structural constituent. ${ }^{1-3}$ The strain-induced martensitic transformation of retained austenite during cold forming, resulting in additional plasticity, stimulated increased research activities to assess the microstructure-property relationships in TRIP-aided steels. ${ }^{2-4}$ The demand for ultra-high-strength steels can be satisfied when a soft ferritic matrix is replaced by harder bainite. Hence, a growing importance of the AHSSs containing increased bainite amounts can be observed in ${ }^{4-9}$. The desired ductility can be only obtained in advanced carbide-free bainitic steels, achieved with $\mathrm{Si}, \mathrm{Al}$, or $\mathrm{Si}-\mathrm{Al}$ alloying. Unfortunately, Al-alloyed steels have a lower solid-solution strengthening effect. Thus, increased carbon contents are used or microalloying is employed to improve the strength levels with grain refinement and precipitation strengthening, in a similar way as in the HSLA steels. ${ }^{9-12}$ Recently, medium-Mn bainitic-austenitic steels have also been developed. ${ }^{8,13}$ Medium-C or medium-alloyed sheet steels are used for the products capable of mechanical binding and chemical adhesion ${ }^{14}$ or they can be also used for forgings and wires., ${ }^{4,6}$

Bainite-based steels containing large volume fractions of retained austenite can be produced with cold rolling or hot rolling. The knowledge concerning the relationships between the manufacturing conditions, the microstructure and the mechanical properties of coldrolled and annealed products is sufficiently documented in literature studies. ${ }^{5,6,10,14}$ However, there are only few reports on the microstructure-property relationships in hot-rolled medium-C, carbide-free bainitic steels. ${ }^{4,7}$ It is known that thermomechanical processing requires a detailed time-temperature regime during a sheet's cooling. ${ }^{13,15}$ It is especially important for multiphase steels because austenite retention requires one or two isothermal holding steps upon cooling. Isothermal holding of steel at a bainitic transformation temperature is obligatory for the enrichment of austenite in carbon from bainitic ferrite. This schedule is used for bainitic-austenitic 
alloys. ${ }^{9}$ An additional enrichment of austenite in $\mathrm{C}$ can be provided with an isothermal holding step at the intercritical region ${ }^{5,15}$ or using low finishing rolling temperatures. $^{7}$

Mechanical properties of multiphase steels are dependent on the volume fractions and properties of bainite and retained austenite. The final fraction of retained austenite that can be stabilized depends, in turn, on the chemical composition of steel and heat-treatment conditions. However, the most important is the mechanical stability of retained austenite, dependent on its carbon content, size, dislocation density, morphology (blocky, interlath), etc. ${ }^{3-5,10}$ An efficient monitoring of the evolution of retained austenite and strain-induced martensite as a function of strain is crucial for understanding microstructure-property relationships. This approach can be used with typical TRIP-aided ferrite-based steels. ${ }^{1-3,16}$ The aim of the present study is to monitor the evolution of the microstructure of TRIP-aided medium-C bainitic steel.

\section{EXPERIMENTAL PROCEDURE}

The work was focused on monitoring the microstructure evolution of the Si-Al type TRIP-aided steel containing $0.43 \% \mathrm{C}, 1.45 \% \mathrm{Mn}, 0.98 \% \mathrm{Si}, 1.0 \% \mathrm{Al}$, $0.033 \% \mathrm{Nb}, 0.01 \% \mathrm{Ti}, 0.004 \% \mathrm{~S}, 0.01 \% \mathrm{P}$ and $0.0028 \%$ $\mathrm{N}$. The steel was produced with vacuum-induction melting followed by casting under an Ar atmosphere, hot forging and rough rolling to a thickness of $4.5 \mathrm{~mm}$. The chemical composition was designed to obtain a large fraction of retained austenite and carbide-free bainite using the complex $\mathrm{Si}+\mathrm{Al}$ approach. ${ }^{2,3} \mathrm{Nb}$ and Ti microadditions were used to increase the strength level through grain refinement and precipitation strengthening.

The thermomechanical rolling was conducted in 3 passes between $1100{ }^{\circ} \mathrm{C}$ and $750{ }^{\circ} \mathrm{C}$ to the final thickness of about $2 \mathrm{~mm}$. The cooling schedule consisted of the finishing rolling at $750{ }^{\circ} \mathrm{C}$ followed by slow cooling of the sheet samples to a temperature of $600{ }^{\circ} \mathrm{C}$ within $25 \mathrm{~s}$. Immerse cooling of the specimens at a rate of about $50{ }^{\circ} \mathrm{C} / \mathrm{s}$ to an isothermal holding temperature of $450{ }^{\circ} \mathrm{C}$ was the next step. The isothermal holding time was $600 \mathrm{~s}$. Finally, the samples were cooled at a rate of about 0.5 ${ }^{\circ} \mathrm{C} / \mathrm{s}$ to room temperature. Then, the samples with a gauge length of $50 \mathrm{~mm}$ and a width of $12.5 \mathrm{~mm}$ were prepared for the tensile tests carried out at a strain rate of $5 \times 10^{-3} \mathrm{~s}^{-1}$. To monitor the transformation of the retained austenite into martensite as a function of the strain, interrupted tensile tests were carried out. The tensile tests were interrupted at different tensile strains in steps of $5 \%$ followed by EBSD investigations to determine the volume fraction of the remaining austenite at a particular strain.

Metallographic specimens were taken along the rolling and tensile directions. Scanning electron microscopy (SEM) and transmission electron microscopy (TEM) were used to reveal morphological details of the microstructure. Additionally, orientation imaging microscopy (OIM) using SEM was applied. Metallographic observations were carried out with the SUPRA 25 SEM using BSE electrons. Observations were performed on nitaletched samples at an accelerating voltage of $20 \mathrm{kV}$. The EBSD technique was carried out using the Inspect $F$ SEM equipped with Schottky field emission. After classical grinding and polishing, the specimens were polished with $\mathrm{Al}_{2} \mathrm{O}_{3}$ with a granularity of $0.1 \mu \mathrm{m}$. The final step of the sample preparation was their ion polishing using the GATAN 682 PECS system. Thin-foil investigations were carried out with JEOL JEM 3010 at an accelerating voltage of $200 \mathrm{kV}$ using a mixture of 490 $\mathrm{mL} \mathrm{H}_{3} \mathrm{PO}_{4}+7 \mathrm{~mL} \mathrm{H}_{2} \mathrm{SO}_{4}+50 \mathrm{~g} \mathrm{CrO}_{3}$ as the electrolyte for the sample preparation.

A determination of the retained austenite fraction and its carbon content after the thermomechanical rolling was performed using the X-ray phase analysis based on the Rietveld method. X-ray tests were done using a Philips PW 1140 diffractometer with Co radiation. The positions of the maxima of the diffraction lines of the austenitic phase were used to determine the lattice constant of austenite $\left(a_{\gamma}\right)$. This parameter is necessary to calculate the carbon content in the retained austenite $\left(\mathrm{C}_{\gamma}\right)$ using the following formula: $a_{\gamma}=0.3578+0.0033 \mathrm{C}_{\gamma} \cdot{ }^{17}$ The fraction of the retained austenite at a particular strain $((5,10,15,18.4) \%)$ was determined with EBSD as the average value of three measurements. A magnification lower than 3000-times was applied to obtain reliable quantitative results.

\section{RESULTS AND DISCUSSION}

The initial microstructure of the steel after the thermomechanical rolling and isothermal holding at a temperature of $450{ }^{\circ} \mathrm{C}$ is presented in Figure 1. It consists of bainite, fine-grained ferrite $(F)$ and retained austenite (RA). The structural constituents are characterized by a significant refinement related to a large population of nucleation sites in the $\gamma \rightarrow \alpha$ transformation after the finishing rolling at a temperature of $750{ }^{\circ} \mathrm{C}$. The largest amount of retained austenite occurs between the laths of bainitic ferrite $(\mathrm{BF})$, while blocky grains of the $\gamma$ phase, of up to about $4 \mu \mathrm{m}$, are located in the boundary regions of the bainitic-austenitic (BA) islands. The interlath retained austenite takes the form of continuous or interrupted laths or small regions located in the bainitic islands (Figure 1b). The average size of ferrite grains is approximately $5 \mu \mathrm{m}$.

The amount of the retained austenite in the initial state determined with an X-ray examination is $17.6 \%$. This result is in good agreement with the EBSD measurements, showing that the retained-austenite fraction reaches $17.1 \%$ (Table $\mathbf{1}$ ). The stabilization of the large fraction of the retained austenite is due to its high carbon content $w\left(\mathbf{C}_{\gamma}=1.64 \%\right)$. The enrichment of austenite in 

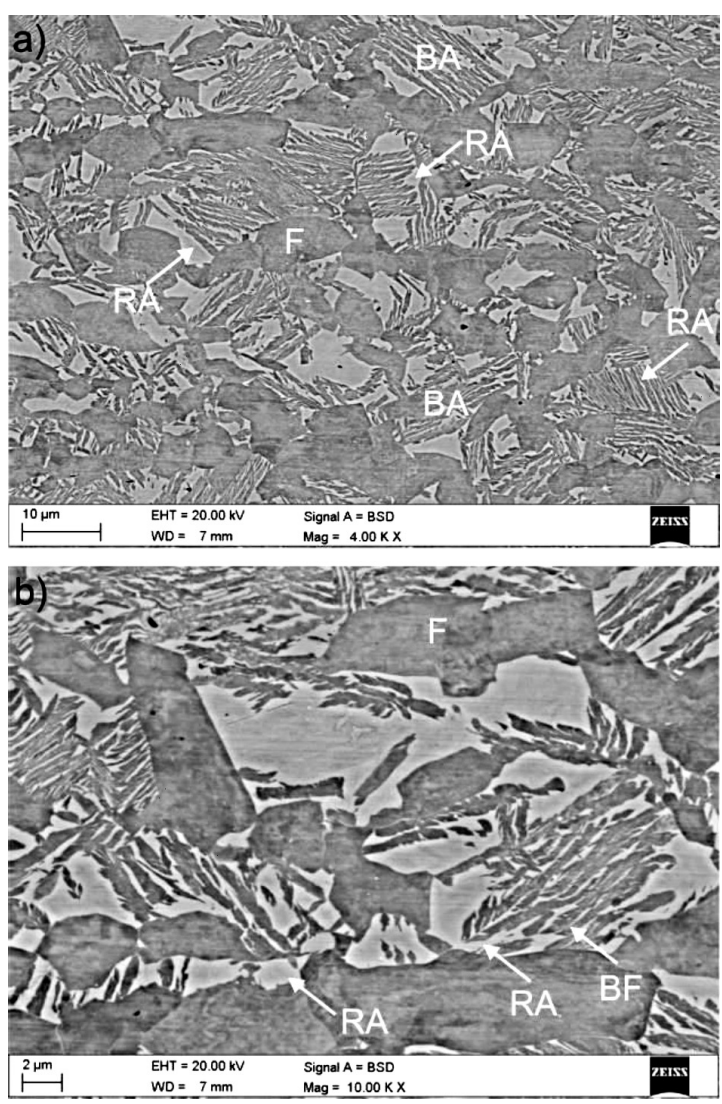

Figure 1: SEM micrographs of the: a) bainitic-ferritic steel containing blocky and interlath retained austenite after thermomechanical rolling, b) morphological details of the bainitic-austenitic (BA) islands; F ferrite, BA - bainitic-austenitic islands, RA - retained austenite, BF bainitic ferrite

Slika 1: SEM-posnetka bainitno-feritnega jekla, ki vsebuje: a) kockast in medlamelni zaostali avstenit, po termomehanskem valjanju, b) detajli morfologije bainitno-avstenitnih (BA) otočkov; F - ferit, BA bainitno-avstenitni otočki, RA - zaostali avstenit, BF - bainitni ferit

carbon was possible due to its partitioning from polygonal and bainitic ferrite during the slow cooling of the sheet samples during the $\gamma \rightarrow \alpha$ transformation and subsequent isothermal holding at $450{ }^{\circ} \mathrm{C}$ for $600 \mathrm{~s}$. This $\mathrm{C}$ content is higher when compared to the other TRIPaided ferrite-based steels $\left.w\left(\mathrm{C}_{\gamma} \approx 1.0-1.4 \%\right)\right)^{2,3,7,16,17}$ Due to the very low finishing rolling temperature $\left(750{ }^{\circ} \mathrm{C}\right)$ almost all the austenite grains are pancaked (not recrystallized) during the bainitic transformation. Thus, both the blocky grains and the layers of the retained austenite remain heavily deformed and exhibit a high dislocation density.

At a strain of $5 \%$ the amount of the retained austenite decreases to about $13.1 \%$ (Table 1), which corresponds to $23 \%$ of the initial amount of the $\gamma$ phase transformed into martensite. The evidence of the strain-induced martensitic transformation at the strain of $5 \%$ is found on the micrographs in Figure 2. It can be seen that the strain-induced martensite forms in the largest grains of the retained austenite, usually located on the boundaries of the bainitic-austenitic islands. On
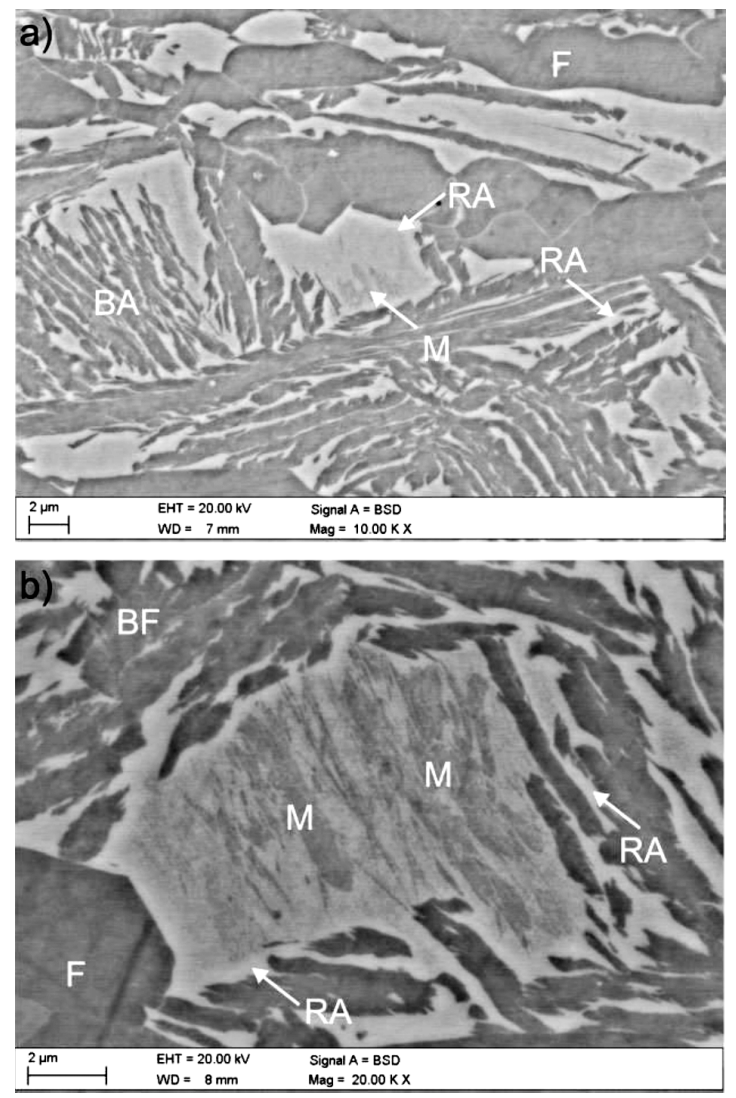

Figure 2: SEM micrographs showing strain-induced martensite in blocky grains of retained austenite at $5 \%$ strain; magnifications of: a) 10000-times and b) 20000-times; F - ferrite, BA - bainitic-austenitic islands, RA - retained austenite, BF - bainitic ferrite, M strain-induced martensite

Slika 2: SEM-posnetka, ki prikazujeta napetostno induciran martenzit v kockastih zrnih zaostalega avstenita pri raztezku $5 \%$; povečava: a) 10000-kratna in b) 20000-kratna; F - ferit, BA - bainitno-avstenitni otočki, RA - zaostali avstenit, BF - bainitni ferit, M - deformacijsko induciran martenzit

the other hand, the laths of the retained austenite located between the bainitic-ferrite laths are mechanically stable.

Table 1: Retained-austenite fractions after thermomechanical rolling $(0 \%$ strain) and at particular strains determined with the EBSD technique

Tabela 1: Delež zaostalega avstenita, določenega z EBSD-tehniko, po termomehanskem valjanju (0 \% raztezka) in pri določenih raztezkih

\begin{tabular}{|c|c|c|c|c|}
\hline $0 \%$ & $5 \%$ & $10 \%$ & $15 \%$ & $18.4 \%$ \\
\hline $17.1 \pm 1.2$ & $13.1 \pm 1.4$ & $11.2 \pm 1.3$ & $9.0 \pm 1.0$ & $6.8 \pm 1.1$ \\
\hline
\end{tabular}

Figure 3 shows EBSD maps registered at a strain of $10 \%$. Comparing the image quality (IQ) map (Figure 3a) and phase map (Figure 3b) it is possible to identify particular structural constituents. In the grey-scale IQ map the retained austenite regions correspond to the dark areas of a poor diffraction quality. The IQ factor represents a quantitative description of the sharpness of the EBSD pattern. A lattice distorted by crystalline defects such as dislocations and grain/subgrain boundaries has a distorted Kikuchi pattern, leading to lower IQ values. ${ }^{1,2}$ 

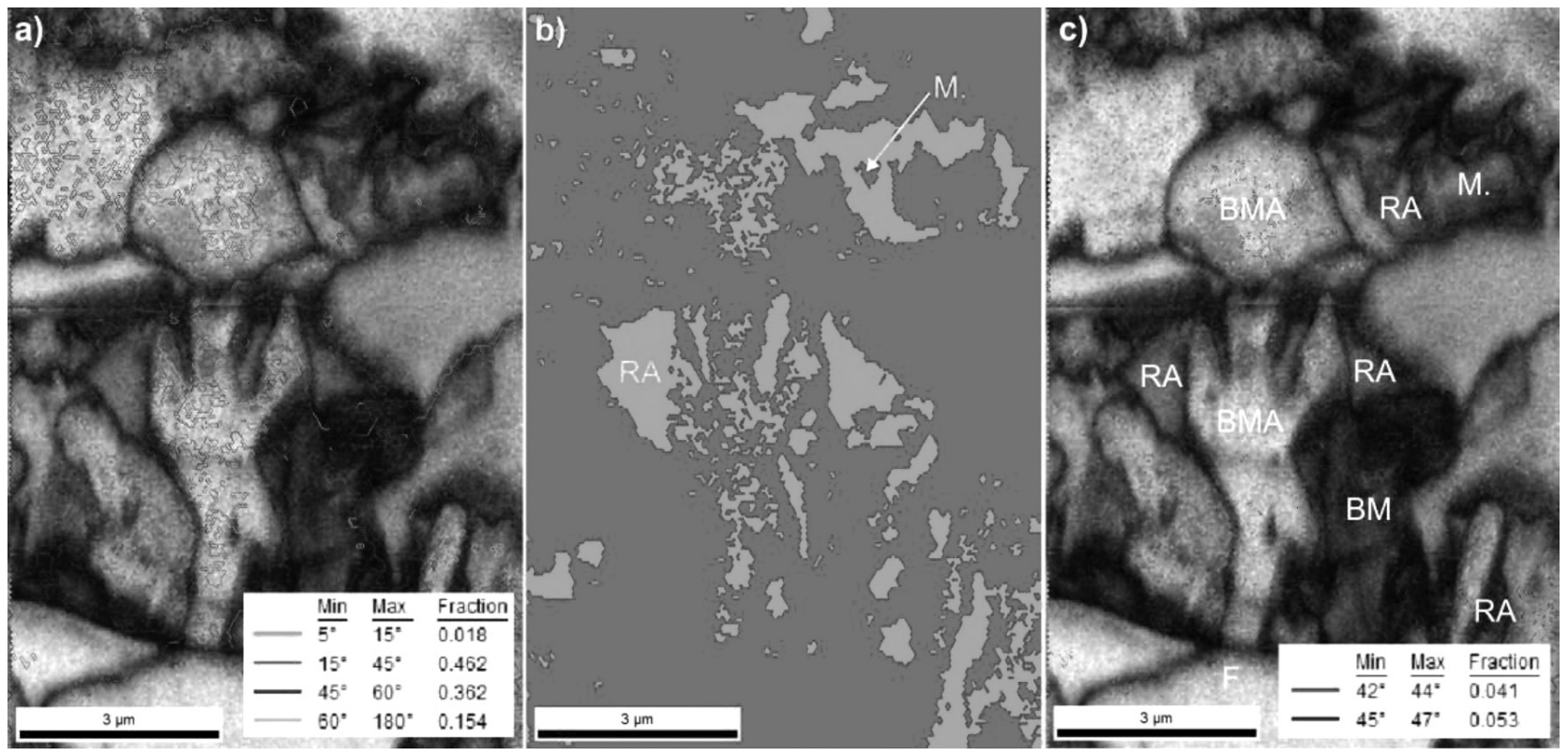

Figure 3: a) Image quality (IQ) map with misorientation angles, b) phase map showing retained austenite - RA regions, and c) IQ map with misorientation angles corresponding to the Kurdjumov-Sachs $\left(42-44^{\circ}\right)$ and Nishiyama-Wasserman $\left(45-47^{\circ}\right)$ relationships at $10 \%$ strain; F ferrite, BMA - bainitic-martensitic-austenitic constituents, RA - retained austenite, BM - bainitic-martensitic constituents, M - strain-induced martensite

Slika 3: a) Posnetek področja kvalitete (IQ) z razporeditvijo slabo orientiranih zrn, b) načrt faz prikazuje zaostali avstenit - RA področja in c) načrt slabo orientiranih zrn po odvisnostih Kurdjumov-Sachs $\left(42-44^{\circ}\right.$ ) in Nishiyama-Wasserman $\left(45-47^{\circ}\right)$ pri raztezku $10 \%$; F - ferit, BMA bainitno-martenzitno-avstenitne sestavine, RA - zaostali avstenit, BM - bainitno-martenzitne sestavine, M - deformacijsko induciran martenzit

Hence, the strain-induced martensite can be distinguished from the other BCC phases (bainitic ferrite and polygonal ferrite) because it has the most defected structure and, thus, it is characterized by the poorest diffraction quality. Additionally, Wasilkowska et al. ${ }^{2}$, Zaefferer el al. ${ }^{3}$ and Petrov et al. ${ }^{16}$ reported that bainitic ferrite and martensite can be indentified if we know special crystallographic orientations between these BCC phases and retained austenite. It is known that the KurdjumovSachs (KS) orientation shows a misorientation angle of $43^{\circ}$, whereas the Nishiyama-Wasserman (NW) orientation shows a $46^{\circ}$ angle. During deformation they are mixed with each other. The way to distinguish them is to analyse the rotation-axis distributions. They are around $<0.180 .180 .97>$ and $<0.20 .080 .98>$ for the KS and NW, respectively.

Fortunately, the characteristic misorientation angles fulfilling the Kurdjumov-Sachs and Nishiyama-Wasserman relationships are sufficiently different to be distinguished using the EBSD mapping. Hence, Figure 3c shows the IQ map with the angles corresponding to the KS and NW relationships with a deviation of $\pm 1^{\circ}$. It is clear that these special angles are mainly located between the retained austenite (RA) and strain-induced martensite (M). The strongly defected strain-induced martensite occurs as dark regions in the phase map. The transformation causes a gradual fragmentation of the retained-austenite regions. Thus, bainitic-martensiticaustenitic constituents (BMA) are formed.
A further increase in the strain to $15 \%$ causes the amount of the retained austenite to decrease to about $9 \%$ (Table 1). The martensitic transformation takes place in large blocky grains of the retained austenite. The initiation of the transformation at smaller blocky grains located in the BA regions can be also observed (Figure 4). However, a high content of $\mathrm{C}$ in the retained austenite results in the lack of transformation of the $\gamma$ phase layers. According to the literature data $2,3,7,9$ the carbon content in the blocky grains is smaller when compared to retained-austenite films. The reason is a longer diffusion path of carbon in the relatively large blocky grains. Thus, the center of a grain has a smaller amount of carbon compared to the external regions of the grain. The same applies to the films of the retained austenite. The diffusion path of $\mathrm{C}$ from the bainitic-ferrite laths into the retained-austenite films is much shorter. Hence, these are mechanically stable upon the straining. Their stability is additionally increased by hard laths of bainitic ferrite, which form a protecting barrier against strain distribution into the retained austenite. ${ }^{4,9}$

The strengthening caused by the complex effects of the thermomechanical processing, strongly defected ferrite and bainite, strain-induced martensite and overstabilized films of the retained austenite, lead to a premature breaking of the samples at an elongation of $18.4 \%$ and UTS of $930 \mathrm{MPa}$. The volume fraction of the retained austenite present after the sample breaking is about $6.8 \%$. It means that about $40 \%$ of the initial amount of the retained austenite is untransformed. This 

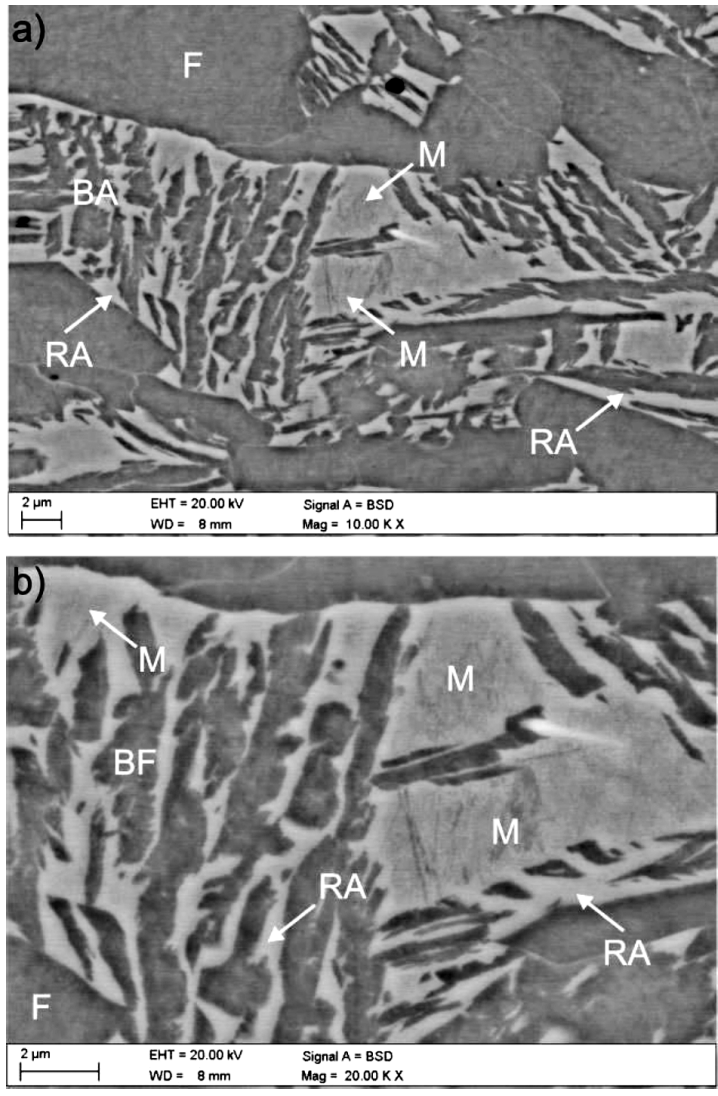

Figure 4: SEM micrographs showing strain-induced martensite in small blocky grains of retained austenite located in BA regions at $15 \%$ strain: a) magnifications of 10000-times and b) 20000-times; F ferrite, BA - bainitic-austenitic islands, RA - retained austenite, BF bainitic ferrite, $\mathrm{M}$ - strain-induced martensite

Slika 4: SEM-posnetka deformacijsko induciranega martenzita $v$ kockastih zrnih zaostalega avstenita v območjih BA pri raztezku $15 \%$ : a) povečava 10000-kratna in b) 20000-kratna; F - ferit, BA - bainitno-avstenitni otočki, RA - zaostali avstenit, BF - bainitni ferit, M deformacijsko induciran martenzit

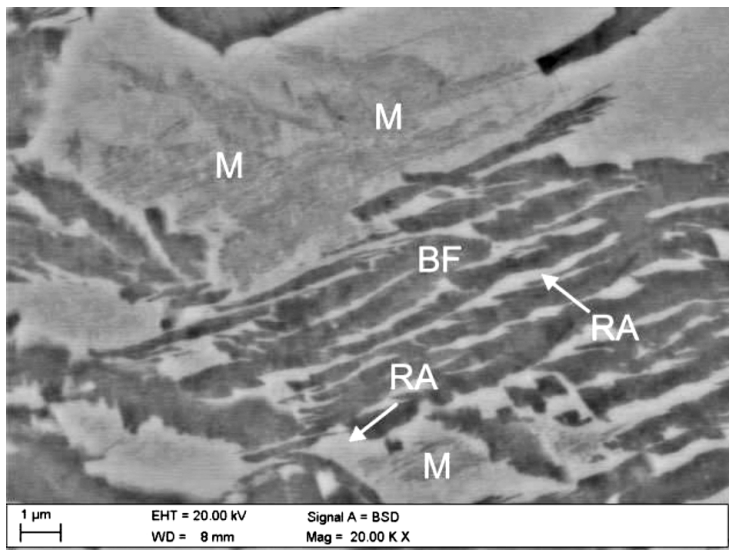

Figure 5: SEM micrograph showing strain-induced martensite in blocky grains of retained austenite and stable interlath retained austenite at rupture strain of $18.4 \%$; RA - retained austenite, $\mathrm{BF}$ bainitic ferrite, $\mathrm{M}$ - strain-induced martensite

Slika 5: SEM-posnetek deformacijsko induciranega martenzita $v$ kockastih zrnih zaostalega avstenita in stabilen zaostali avstenit med lamelami pri raztezku 18,4 \% ob porušitvi; RA - zaostali avstenit, BF - bainitni ferit, $\mathrm{M}$ - deformacijsko induciran martenzit phase remains mainly in the form of thin layers and films located between the hard laths of bainitic ferrite (Figure 5). Firstly, the high mechanical stability of the retained austenite results from its high $\mathrm{C}$ concentration of $1.64 \%$. Secondly, it is due to the fragmentation of the $\gamma$-phase particles and the compressive stresses caused by the hard
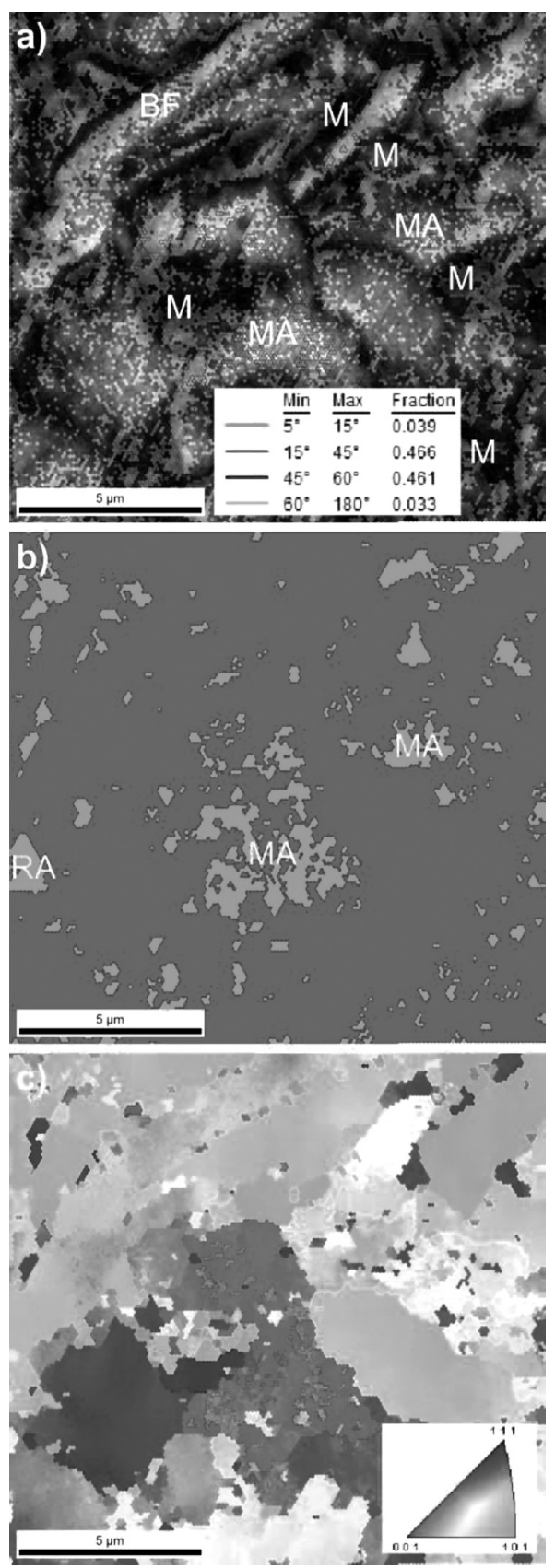

Figure 6: a) Image quality (IQ) map with misorientation angles, b) phase map showing retained austenite - RA regions, and c) inverse pole-figure map at rupture strain of $18.4 \%$; BF - bainitic ferrite, RA retained austenite, MA - martensitic-austenitic constituents, M martensite

Slika 6: a) Posnetek razporeditve kvalitete (IQ) s področij slabo orientiranih zrn, b) razporeditev faz prikazuje zaostali avstenit - RA področja in c) razporeditev inverznih polovih figur pri raztezku $18,4 \% \mathrm{ob}$ porušitvi; BF - bainitni ferit, RA - zaostali avstenit, MA - martenzitno-avstenitne sstavine, $\mathrm{M}$ - martenzit 


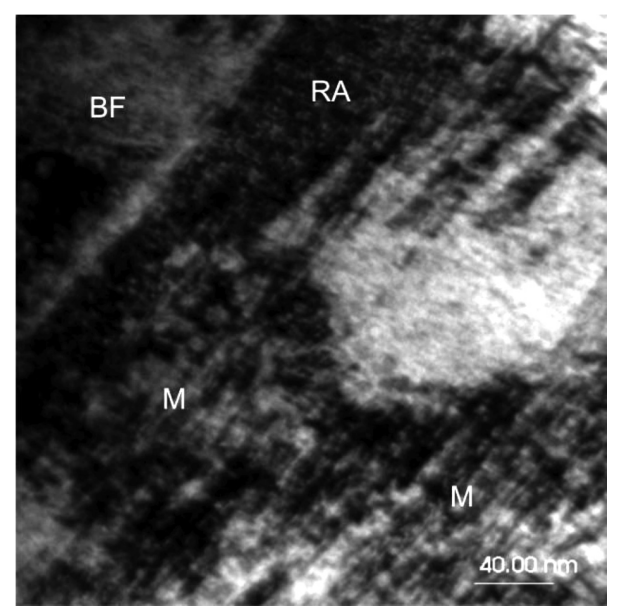

Figure 7: TEM micrograph showing the plate morphology of straininduced martensite at $18.4 \%$ strain; BF - bainitic ferrite, RA retained austenite, $\mathrm{M}$ - strain-induced martensite

Slika 7: TEM-posnetek prikazuje morfologijo plošč deformacijsko induciranega martenzita pri raztezku $18,4 \%$; BF - bainitni ferit, RA zaostali avstenit, $\mathrm{M}$ - deformacijsko induciran martenzit

laths of bainitic ferrite. Finally, the stabilization of the $\gamma$ phase is favoured due to a high density of the dislocations in this phase remaining after the thermomechanical processing. 7

At the fracture strain, the IQ map (Figure 6a) no longer coincides exactly with the inverse pole-figure map (Figure 6c) showing the orientations of individual grains. It is a result of a strongly defected multiphase microstructure. The brightest areas in Figure 6 correspond to the occurrence of defected ferrite and bainitic ferrite, while dark areas of a poor diffraction quality can be identified as the retained austenite and martensite. The particles of the strain-induced martensite are the reason of a substantial fragmentation of the retained-austenite regions. Thus, martensitic-austenitic (MA) regions are formed (Figure 6b). A transmission electron micrograph reveals that the strain-induced martensite has a fine-plate morphology (Figure 7). It is formed from the retained austenite containing about the mass fraction $w(\mathrm{C})=1.64 \%$. This high carbon concentration determines the plate morphology of the stain-induced martensite.

\section{CONCLUSIONS}

The thermomechanically processed, medium-C bainitic steel contains a large volume fraction of retained austenite (about $17 \%$ ), appearing as layers between the bainitic-ferrite laths and blocky grains located in the boundary regions of bainitic-austenitic islands. The morphology of the retained austenite affects the transformation behaviour of this phase into martensite. The blocky grains of the retained austenite gradually transform into strain-induced martensite as a function of the increasing strain. On the other hand, the interlath retained austenite, more enriched in carbon than the blocky grains, is stable upon the straining not providing a TRIP effect. The mechanical stability of the retained austenite is too high especially due to its high average carbon content $\left(w\left(\mathbf{C}_{\gamma}=1.64 \%\right)\right.$. The high dislocation density, the progressive fragmentation of the retained austenite (its size) and the compressive stresses caused by the bainitic-ferrite laths and strain-induced martensite are equally important for the mechanical stabilization of the retained austenite. It can be concluded that polygonal ferrite and the subsequent partitioning of $\mathrm{C}$ during the $\gamma \rightarrow \alpha$ transformation are not necessary for fine-grained, thermomechanically processed, medium-C steel. Overstabilization of the retained-austenite layers should be avoided by producing homogeneous bainitic-austenitic microstructures with a lower $\mathrm{C}$ content in the $\gamma$ phase.

\section{REFERENCES}

${ }^{1}$ A. J. DeArdo, C. I. Garcia, K. Cho, M. Hua, Mater. Manuf. Proc., 25 (2010), 33-40, doi:10.1080/10426910903143415

${ }^{2}$ A. Wasilkowska, R. Petrov, L. Kestens, E. A. Werner, C. Krempaszky, S. Traint, A. Pichler, ISIJ Int., 46 (2006), 302-309, doi:10.2355/isijinternational.46.302

${ }^{3}$ S. Zaefferer, J. Ohlert, W. Bleck, Acta Mater., 52 (2004), 2765-2778, doi:10.1016/j.actamat.2004.02.044

${ }^{4}$ K. I. Sugimoto, S. Sato, G. Arai, Mater. Sci. Forum, 638-642 (2010), 3074-3079, doi:10.4028/www.scientific.net/MSF.638-642.3074

${ }^{5}$ A. Kokosza, J. Pacyna, Arch. Metall. Mater., 59 (2014), 1017-1022, doi:10.2478/amm-2014-0170

${ }^{6}$ S. Wiewiorowska, Arch. Metall. Mater., 58 (2013), 573-576, doi:10.2478/amm-2013-0040

${ }^{7}$ A. Basuki, E. Aernoudt, J. Mater. Proc. Tech., 89-90 (1999), 37-43, doi:10.1016/S0924-0136(99)00037-0

${ }^{8}$ A. Grajcar, R. Kuziak, Adv. Mater. Res., 314-316 (2011), 119-122, doi:10.4028/www.scientific.net/AMR.314-316.119

${ }^{9}$ J. Adamczyk, A. Grajcar, J. Micro. Mater. Prop., 2 (2007), 112-122, doi:10.1504/IJMMP.2007.014305

${ }^{10}$ F. G. Caballero, C. Garcia-Mateo, J. Chao, M. J. Santofimia, C. Capdevila, C. G. de Andres, ISIJ Int., 48 (2008), 1256-1262, doi:10.2355/isijinternational.48.1256

${ }^{11}$ D. A. Skobir, M. Godec, M. Balcar, M. Jenko, Mater. Tehnol., 44 (2010) 6, 343-347

${ }^{12}$ M. Opiela, A. Grajcar, Arch. Civ. Mech. Eng., 12 (2012), 427-435, doi:10.1016/j.acme.2012.06.013

${ }^{13}$ A. Grajcar, S. Lesz, Mater. Sci. Forum, 706-709 (2012), 2124-2129, doi:10.4028/www.scientific.net/MSF.706-709.2124

${ }^{14}$ O. Matsumura, Y. Sakuma, H. Takechi, Scripta Metall., 21 (1987), 1301-1306, doi:10.1016/0036-9748(87)90103-7

${ }^{15}$ B. Barucija, M. Oruc, O. Beganovic, M. Rimac, S. Muhamedagic, Mater. Tehnol., 47 (2013) 5, 665-668

${ }^{16}$ R. Petrov, L. Kestens, Y. Houbaert, Mater. Sci. Forum, 550 (2007), 1-6, doi:10.4028/www.scientific.net/MSF.550.1

${ }^{17}$ Z. C. Wang, S. J. Kim, C. G. Lee, T. H. Lee, J. Mater. Proc. Tech., 151 (2004), 141-145, doi:10.1016/j.jmatprotec.2004.04.029 